\title{
Phytometric and Productive Characteristics of Safflower Submitted to Phosphate Fertilization in the Oxisol of the Brazilian Cerrado
}

\author{
Edna Maria Bonfim-Silva*, Luiz Fernando Santos Miranda, Laura Cristina Rezende das Neves, \\ Helon Hébano de Freitas Sousa, Jefferson Vieira José
}

Department of Agricultural Engineering, Federal University of Mato Grosso, Rondonópolis, Brazil

Email: *embonfim@hotmail.com

How to cite this paper: Bonfim-Silva, E.M., Miranda, L.F.S., das Neves, L.C.R., de Freitas Sousa, H.H. and José, J.V. (2017) Phytometric and Productive Characteristics of Safflower Submitted to Phosphate Fertilization in the Oxisol of the Brazilian Cerrado. American Journal of Plant Sciences, 8, 2966-2976.

https://doi.org/10.4236/ajps.2017.812201

Received: September 30, 2017

Accepted: November 10, 2017

Published: November 13, 2017

Copyright $\odot 2017$ by authors and Scientific Research Publishing Inc. This work is licensed under the Creative Commons Attribution International License (CC BY 4.0).

http://creativecommons.org/licenses/by/4.0/

\begin{abstract}
The safflower (Carthamus tinctorius L.), in particular, has been soaring in significance as an alternative for oil and biodiesel production. In this context, the goal of this study was to assess the influence exerted by phosphate fertilization on the phytometric and productive characteristics of the safflower raised on the Oxisol of the Cerrado. The experiment was performed in a greenhouse, using pots of $3 \mathrm{dm}^{-3}$ in volume. Adopting the completely randomized design, five doses of phosphorus $\left(\mathrm{P}_{2} \mathrm{O}_{5}: 0,90,180,360\right.$ and $\left.540 \mathrm{mg} \cdot \mathrm{dm}^{-3}\right)$ and six replicates were included. The following variables were estimated, viz., number of leaves, plant height, and stem diameter, besides chlorophyll index (SPAD index), number of chapters and shoot dry matter. Barring the shoot dry matter and number of chapters, all the other variables were evaluated on days 30 and 45 after the plants were transplanted. Data were submitted to analysis of variance at $1 \%, 5 \%$ and $10 \%$ probabilities, and regression analysis, at $1 \%$ and $5 \%$ probabilities, respectively. All the variables revealed significant differences and adjustments to the linear regression model $(\mathrm{P}<0.1)$, excepting the SPAD index on day 30 after the plant emergence which was adjusted to the quadratic regression model. The highest findings of 24.47 for leaf number, $34.97 \mathrm{~cm}$ for plant height, $3.76 \mathrm{~mm}$ for stem diameter, 64.76 for chlorophyll index, 5 units for the number of chapters and $3.45 \mathrm{~g}$ for dry shoot mass were recorded in response to the highest phosphorus dose in the experimental range $\left(\mathrm{P}_{2} \mathrm{O}_{5}: 540\right.$ $\left.\mathrm{mg} \cdot \mathrm{dm}^{-3}\right)$. Phosphate fertilization was observed to affect the phytometric characteristics and boost the development of the safflower plants cultivated in the Cerrado Oxisol, substantiating that safflower could be a viable cash crop that can be established in the Brazilian Cerrado.
\end{abstract}




\section{Keywords}

Carthamus tinctorius L., Alternative Culture for Biodiesel, Oleaginous

\section{Introduction}

Safflower (Carthamus tinctorius $\mathrm{L}$.) holds great promise as a potential alternative to oil and biodiesel production [1]. This annual crop from the Asteraceae family, to which the sunflower (Helianthus annuus L.) belongs, originated somewhere between Asia and Africa [2] [3].

With seeds high in oil content (27\% to $37 \%$ ) [4], besides minerals ( $\mathrm{Zn}, \mathrm{Cu}$, $\mathrm{Mn}$, and $\mathrm{Fe})$, vitamins (thiamine and $\beta$-carotene) and tocopherols $(\alpha, \beta$, and $\gamma)$ [5], it produces high-quality oil which is tasteless and colorless. As the oil is similar in composition to that of sunflower (Helianthus annuus L.), it can also find extensive use in human consumption and for industrial purposes [6] [7].

In Brazil, studies on safflower culture are still in the inceptive stage and, as the economic potential and environmental significance of this crop are increasingly becoming known, further researchers focused on the productive process from the perspective of soil fertility and plant nutrition are required [8] [9] [10] [11].

The roughly 14.55 million hectares [12] demarcated in the state of Mato Grossoin 2017, for raising cereals, legumes and oilseeds can be utilized to include safflower cultivation as a profitable option in this production process. However, in the tropical regions, where soils like Oxisol cover a large area of the Cerrado, the phosphorus content is low. This is because of the phenomenon of phosphorus fixation in the soil components which act as a considerable sink for phosphorus, requiring the application of phosphorus as fertilizer in doses several times greater than those required by the crops [13]. However, in Brazil, phosphorus is provided in the form of soluble phosphates, which intensely react in the soil, and support their absorption by the plant roots.

In light of these facts, this study aimed at assessing the effect of phosphate fertilization on the phytometric and productive characteristics of the safflower, cultivated in the Oxisol of the Cerrado.

\section{Material and Methods}

The experiment was conducted between September and December of 2016 in a greenhouse at the Federal University of Mato Grosso, University Campus of Rondonópolis, with the coordinates of $16^{\circ} 27^{\prime} 49^{\prime \prime} \mathrm{S}$ latitude, $50^{\circ} 34^{\prime} 47^{\prime \prime} \mathrm{W}$ longitude, at $284 \mathrm{~m}$ altitude. The region, according to the Köppen classification, experienced Aw type of climate, which is hot and humid, characterized by the rainy season in the summer and drought in the winter [14]. The temperature during the period varied between $24.1^{\circ} \mathrm{C}$ and $30.6^{\circ} \mathrm{C}$, and the relative humidity between $56 \%$ and $69 \%$. The day length was 12.2 hours.

The completely randomized experimental design was selected, including five 
doses of phosphorus $\left(\mathrm{P}_{2} \mathrm{O}_{5}: 0,90,180,360\right.$ and $\left.540 \mathrm{mg} \cdot \mathrm{dm}^{-3}\right)$ with six replicates, using the BAG-IMA MT 187 safflower cultivar, obtained from the germplasm bank of Mato Grosso Cotton Institute (IMAmt), Brazil.

The soil, from a region supporting Cerrado vegetation, was collected from 0 to $0.2 \mathrm{~m}$ depth and sieved through a mesh with $4 \mathrm{~mm}$ sized openings to fill the container; it was also passed through a $2 \mathrm{~mm}$ mesh for chemical and granulometric characterization [15].

The soil collected from the prescribed depth revealed the chemical characteristics listed: $\mathrm{pH}\left(\mathrm{H}_{2} \mathrm{O}\right)=4.7 ; \mathrm{O} . \mathrm{M}=20.6 \mathrm{~g} \cdot \mathrm{Kg}^{-1} ; \mathrm{P}=1.7 \mathrm{mg} \cdot \mathrm{dm}^{-3}$ (Mehlich-1); $\mathrm{K}$ $=24 \mathrm{mg} \cdot \mathrm{dm}^{-3} ; \mathrm{Ca}=0.2 \mathrm{cmol} \cdot \mathrm{dm}^{-3} ; \mathrm{Mg}=0.2 \mathrm{cmol} \cdot \mathrm{dm}^{-3} ; \mathrm{Al}=0.8 \mathrm{cmol} \cdot \mathrm{dm}^{-3} ; \mathrm{H}+$ $\mathrm{Al}=5.20 \mathrm{cmol} \cdot \mathrm{dm}^{-3} ; \mathrm{CTC}=5.66 \mathrm{cmol}_{c} \cdot \mathrm{dm}^{-3} ; \mathrm{Zn}=0.7 \mathrm{mg} \cdot \mathrm{dm}^{-3} ; \mathrm{Cu}=0.5$ $\mathrm{mg} \cdot \mathrm{dm}^{-3} ; \mathrm{Fe}=194 \mathrm{mg} \cdot \mathrm{dm}^{-3} ; \mathrm{Mn}=13.4 \mathrm{mg} \cdot \mathrm{dm}^{-3} ; \mathrm{B}=0.26 \mathrm{mg} \cdot \mathrm{dm}^{-3}$ and $\mathrm{S}=6.8$ $\mathrm{mg} \cdot \mathrm{dm}^{-3}$. Based on the soil granulometry the following distinctions could be made: $507 \mathrm{~g} \cdot \mathrm{Kg}^{-1}$ of sand, $116 \mathrm{~g} \cdot \mathrm{Kg}^{-1}$ of silt and $377 \mathrm{~g} \cdot \mathrm{Kg}^{-1}$ of clay.

The soil $\mathrm{pH}$ was raised through liming, by implementing the base saturation method [16]. The dolomitic limestone (PRNT of 80.3\%) was incorporated to increase the base saturation to $60 \%$. Post liming, the soil was moistened up to $60 \%$ of its water retention capacity [9], and subjected to a 28 -day incubation period in a sealed plastic bag.

Once the soil was incubated, it was filled with pots $3 \mathrm{dm}^{3}$ in volume. The safflower seedlings were then transplanted into the pots on day 5 post plant emergence. Phosphate fertilization $\left(\mathrm{P}_{2} \mathrm{O}_{5}\right)$ in $90,180,360$ and $540 \mathrm{mg} \cdot \mathrm{dm}^{-3}$ doses was performed on the same day that the seedlings were transplanted, employing simple superphosphate, along with potassium fertilization $\left(200 \mathrm{mg} \cdot \mathrm{dm}^{-3}\right)$ using as a source potassium chloride (PA), pure for the analysis. Nitrogen fertilization was done following the recommended dosage of $200 \mathrm{mg} \cdot \mathrm{dm}^{-3}$ [17], with urea as the source, given in divided doses in solution form, in three equal applications applied at intervals of 10 days from the date of transplanting.

Micronutrient fertilization was accomplished by adding a solution of 1 $\mathrm{mg} \cdot \mathrm{dm}^{-3}$ of $\mathrm{B}$ and $\mathrm{Cu}, 3 \mathrm{mg} \cdot \mathrm{dm}^{-3}$ of $\mathrm{Mn}$ and $\mathrm{Zn}$ and $0.2 \mathrm{mg} \cdot \mathrm{dm}^{-3}$ of Mo [9]. The gravimetric irrigation method was employed, maintaining the moisture at $60 \%$ of the maximum soil water retention capacity [18].

The variables assessed included, number of leaves, plant height, stem diameter, chlorophyll index (SPAD index), and number of chapters and shoot dry matter. On day 62 after transplanting, the plants were cut. Except for the variables shoot dry matter and number of chapters evaluation was done on days 30 and 45 after transplanting.

The variable plant height was determined using a graduated ruler from the ground level to the plant apex. The stem diameter was recorded using a digital caliper, at about $2 \mathrm{~cm}$ from the soil surface. The number of chapters was counted in each experimental plot. The chlorophyll index was obtained from the average of the random readings of five leaves using the Chlorophyll Meter SPAD-502 equipment. 
The shoot dry matter was calculated using the plant material cut on day 62 after transplanting. This material was packed in paper bags and then oven dried with forced air circulation at $65^{\circ} \mathrm{C}$ until constant mass was achieved. The dried samples were then weighed using a semi-analytical balance.

Data were submitted to the Shapiro-Wilk $(\mathrm{P}>0.01)$ and Levene $(\mathrm{P}>0.01)$ tests to check the residual normality and homoscedasticity, respectively. Thereafter, the analysis of variance was performed at $1 \%, 5 \%$ and $10 \%$ probabilities and the findings were submitted to regression analysis at $1 \%$ and $5 \%$ probabilities. The SISVAR statistical software was used [19].

\section{Results and Discussion}

For the variables, number of leaves on days 30 and 45, plant height on day 45, SPAD index on days 30 and 45 , number of chapters and shoot dry matter, the results of the analysis of variance showed significance at $1 \%$. For plant height on day 30 and stem diameter on day 45 the significance was noted at $5 \%$ and for stem diameter on day 30 , the significance was seen at $10 \%$. All the variables were adjusted to the linear regression model (at $1 \%$ probability), barring the SPAD chlorophyll index on day 30 , which was adjusted to the quadratic model at $5 \%$ probability.

The most number of leaves in the assessment on day 30 after transplanting was 8.93 , while on day 45 after transplanting it was 24.47 when the highest phosphorus dose $\left(540 \mathrm{mg} \cdot \mathrm{dm}^{-3}\right)$ was added; this shows a $29.68 \%$ increase in the first instance and $49.86 \%$ in the second when compared to the treatment lacking the phosphorus fertilization (Figure 1).

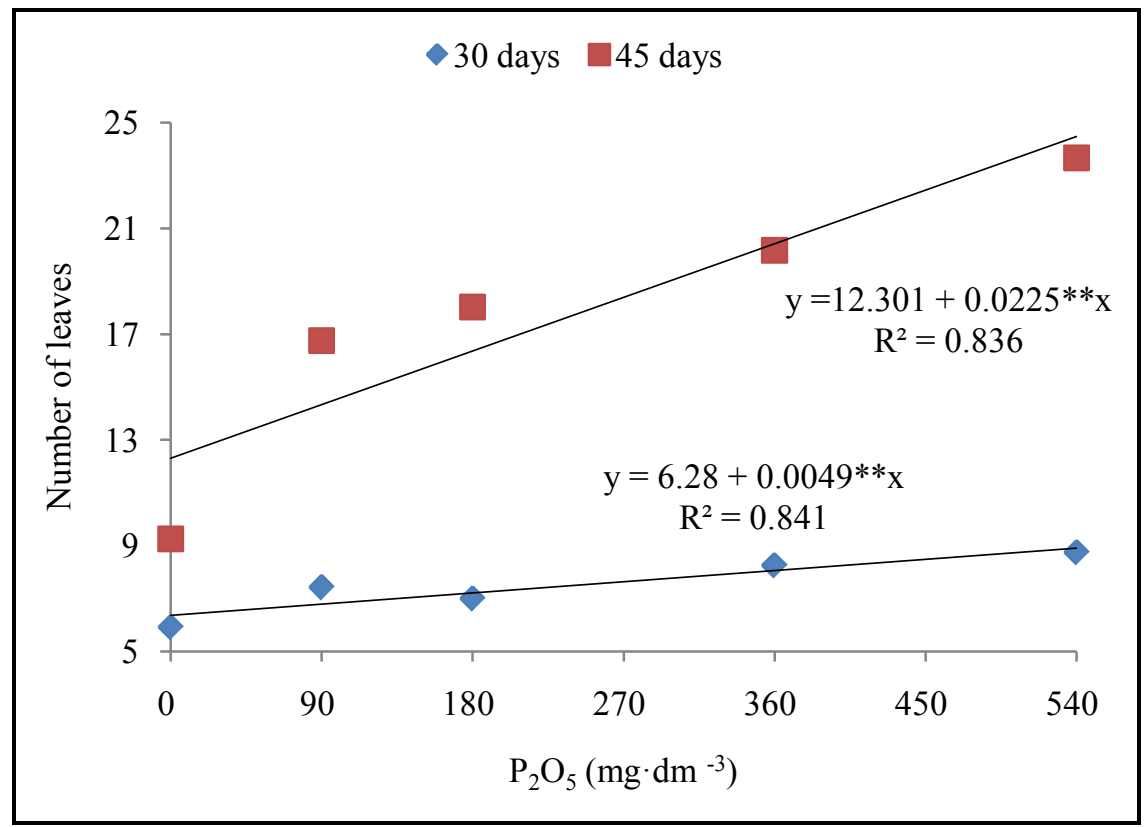

Figure 1. Number of leaves of safflower (Carthamus tinctorius L.) on days 30 and 45 post-transplanting in response to the phosphorus doses $\left(0,90,180,360\right.$ and $540 \mathrm{mg} \cdot \mathrm{dm}^{-3}$ of $\left.\mathrm{P}_{2} \mathrm{O}_{5}\right) .{ }^{* *}$ Significance at $1 \%$. 
The number of leaves in plants belonging to the same family, like sunflower, rises proportionally to the phosphorus doses, showing between $31 \%$ and $35 \%$ increase in comparison to the treatment lacking the phosphate fertilization [20]. Likewise, the safflower culture responded significantly to the raised phosphorus doses $\left(0.04\right.$ to $\left.0.72 \mathrm{~g} \cdot \operatorname{pot}^{-1}\right)$ and produced plants having the most number of chapters [8]. These results may reiterate the crucial role played by phosphorus in the energy metabolism, and the addition of this nutrient induces a higher emission and leaf growth, besides increasing the leaf area [21], which promotes the absorption of solar radiation and, therefore, enhances photoassimilate production [22].

The greatest heights were noted in response to the phosphorus $\left(\mathrm{P}_{2} \mathrm{O}_{5}\right)$ dose of $540 \mathrm{mg} \cdot \mathrm{dm}^{-3}$, registering $20.92 \mathrm{~cm}$ on day 30 and $34.97 \mathrm{~cm}$ on day 45 (Figure 2). On comparison of the plant heights in response to the highest phosphorus dose in the experimental range $\left(540 \mathrm{mg} \cdot \mathrm{dm}^{-3}\right)$ with the treatment that lacked phosphate fertilization, the increments were $30.98 \%$ and $34.97 \%$ on days 30 and 45 , respectively.

Phosphorus is vital to the cell energy transfer, respiration, and photosynthetic processes, and its lack or low availability during the early developmental stages produces a limitation from which the plant does not subsequently recover [23]. Studies were done on the sunflower cultivation established that supplementation with phosphorus doses increased plant growth when compared with the treatment that was denied phosphorus fertilization [20] [24].

The variable stem diameter in response to phosphorus doses was adjusted to the linear regression model (Figure 3), for which the highest findings were 2.72

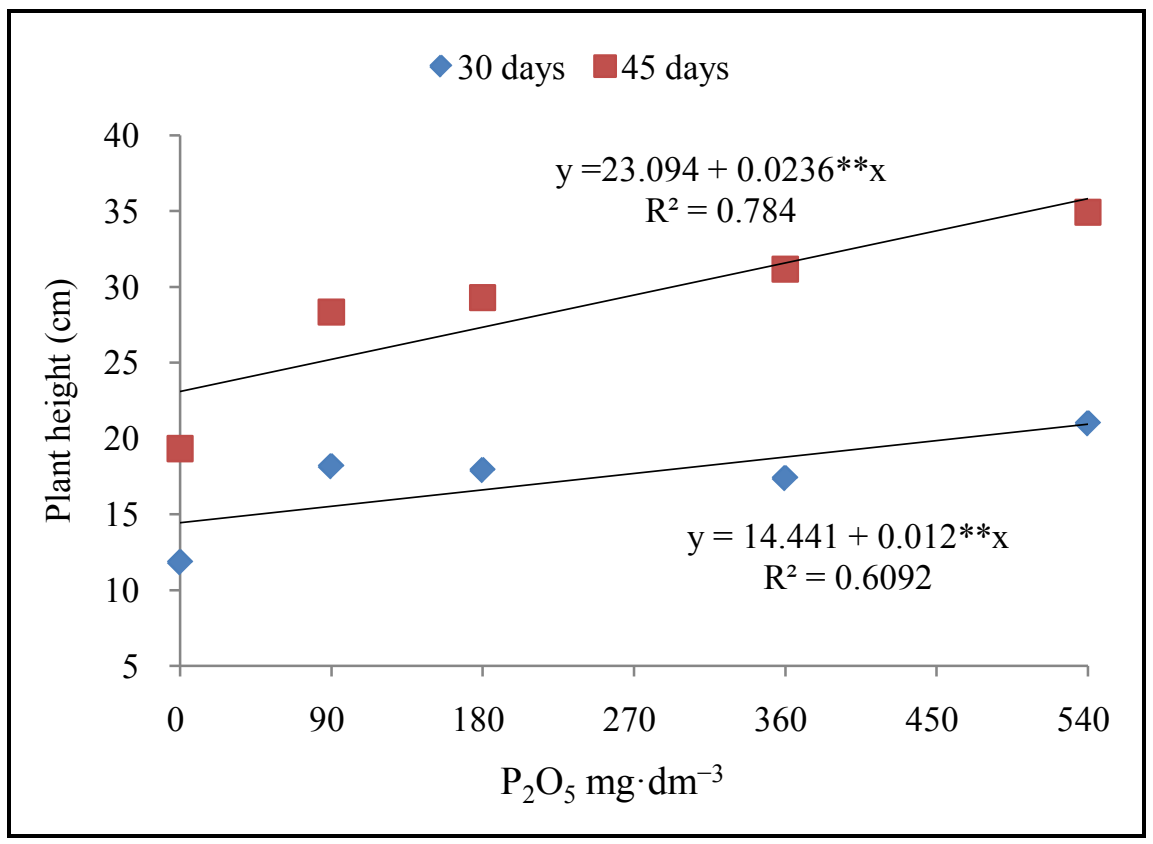

Figure 2. Plant height of the safflower (Carthamus tinctorius L.) on days 30 and 45 post-transplanting, in response to the phosphorus doses $\left(0,90,180,360\right.$ and $540 \mathrm{mg} \cdot \mathrm{dm}^{-3}$ of $\left.\mathrm{P}_{2} \mathrm{O}_{5}\right) \cdot{ }^{* *}$ Significance at $1 \%$. 


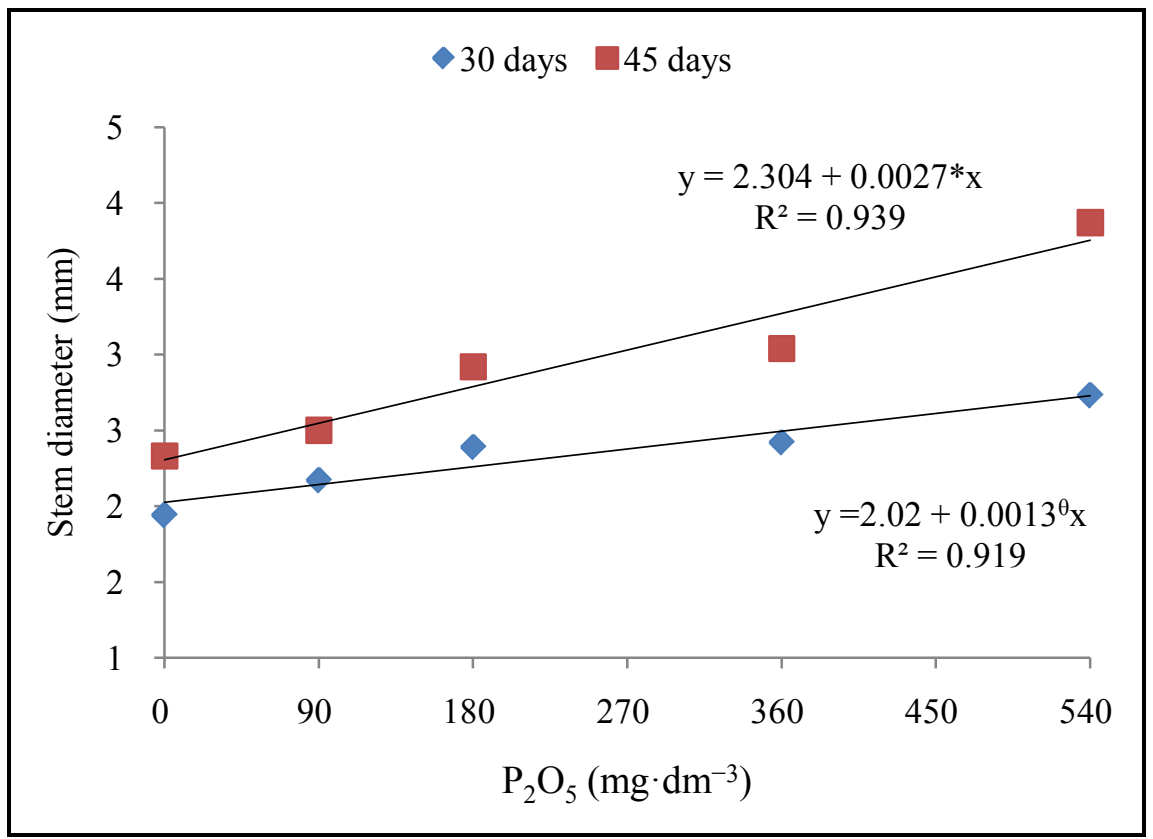

Figure 3. Stem diameter in safflower (Carthamus tinctorius L.) on days 30 and 45 post-transplanting in response to the phosphorus doses $\left(0,90,180,360\right.$ and $540 \mathrm{mg} \cdot \mathrm{dm}^{-3}$ of $\mathrm{P}_{2} \mathrm{O}_{5}$ ), with significance at $10 \%(\theta)$ on day 30 and at $5 \%\left(^{*}\right)$ on day 45 .

$\mathrm{mm}$ and $3.76 \mathrm{~mm}$, on days 30 and 45 after transplanting, respectively. In comparison with the treatment, lacking such fertilization the increase was $25.74 \%$ on day 30 and $38.83 \%$ on day 45 after transplanting.

Phosphorus is vital for the plant processes of cell division, reproduction, metabolism, photosynthesis, respiration, and synthesis of organic substances [25] [26]. Hence, the stem diameter increase is also linked to the rise in the phosphorus supply, which in turn, boosts the production of the photoassimilates stored in the leaves and stem, encouraging the production of the plant structures [27].

On day 30 , the maximum chlorophyll index recorded was 47.53 in response to the $376.23 \mathrm{mg} \cdot \mathrm{dm}^{-3}$ dose, whereas on day 45 , the highest index was 64.76 in response to the $540 \mathrm{mg} \cdot \mathrm{dm}^{-3}$ dose (Figure 4 ). An increase of $18.16 \%$ was noted on day 30 post-transplanting, and of $23.42 \%$ on day 45 . The chlorophyll index showed a tendency to rise in response to the phosphorus supplementation, making it clear that the higher phosphorus concentrations contribute towards higher nutrient utilization and the enhanced chlorophyll content in safflower [9] [28].

The most number of safflower chapters visible on day 62 post-transplanting, was a result of the highest phosphorus dose, which induced the greatest production of this variable (Figure 5). The highest phosphorus dose caused a $54.80 \%$ rise in the number of chapters when compared to the treatment lacking phosphate fertilization (Figure 6). In crops like safflower, as the number of chapters is directly linked to the production, their measurement is of immense significance of [17]. As the genetic variability in the species Carthamus tinctorius L. is 


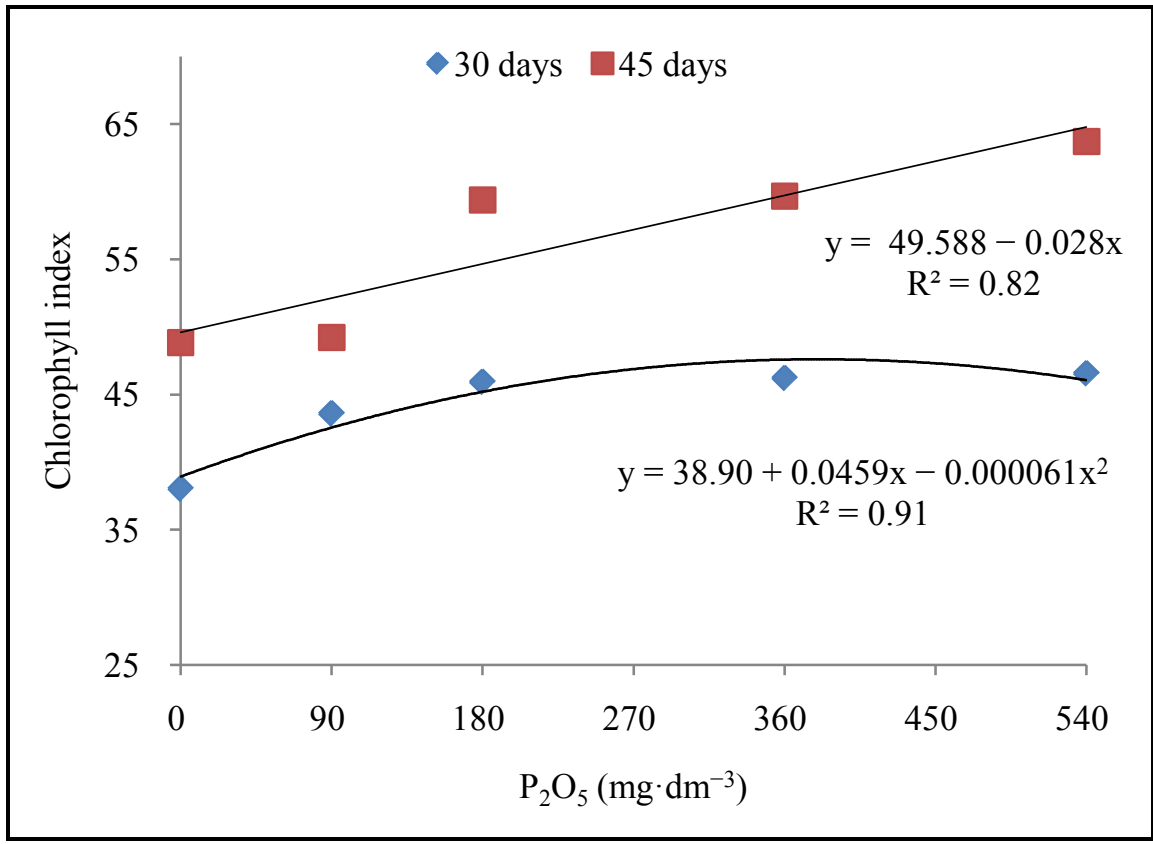

Figure 4. Chlorophyll content (SPAD index) of the safflower (Carthamus tinctorius L.) on days 30 and 45 post-transplanting in response to the phosphorus doses $(0,90,180,360$ and $540 \mathrm{mg} \cdot \mathrm{dm}^{-3}$ of $\mathrm{P}_{2} \mathrm{O}_{5}$ ), ${ }^{* *}$ and ${ }^{*}$ significant at $1 \%$ e $5 \%$, respectively.

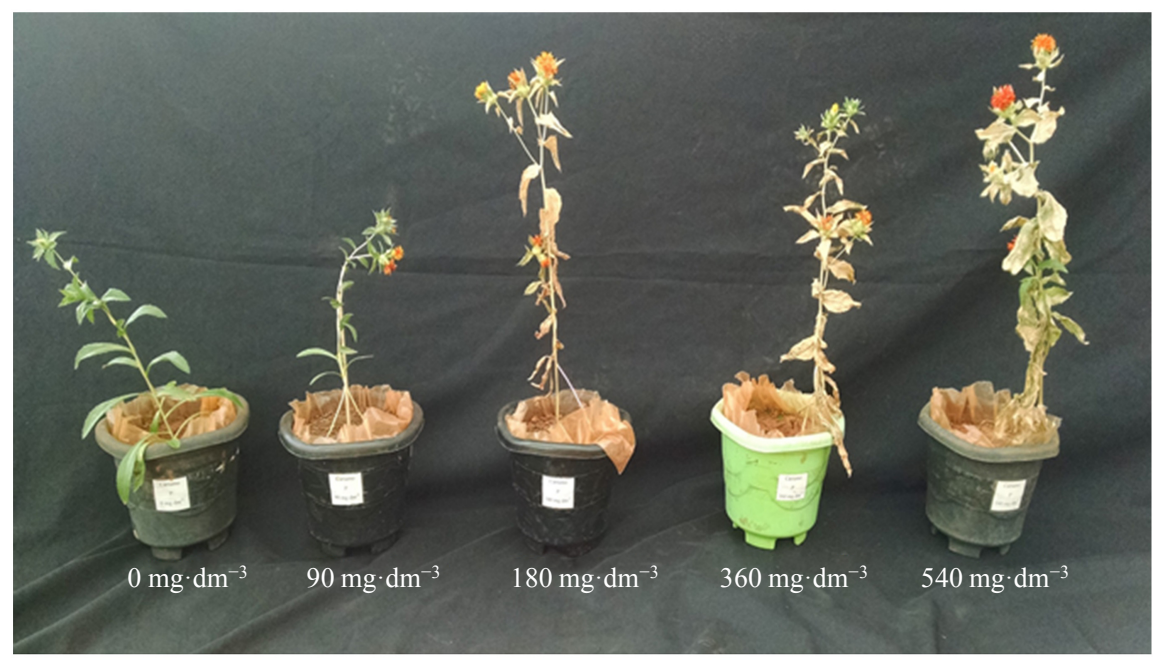

Figure 5. Safflower plants on day 62 post-transplanting submitted to different phosphorus doses $\left(0,90,180,360\right.$ and $540 \mathrm{mg} \cdot \mathrm{dm}^{-3}$ of $\left.\mathrm{P}_{2} \mathrm{O}_{5}\right)$.

very high, the number of chapters may vary in accordance to each genotype - for instance, the PI401475 produces 5, whereas the PI613409 produces 9 [29].

The shoot dry matter production in safflower was adjusted to the linear regression model with the maximum production of $3.45 \mathrm{~g} \cdot \mathrm{pot}^{-1}$ in response to the highest phosphorus dose in the experimental range, indicating a $57.10 \%$ increase (Figure 7).

At the culmination of the experiment, the shoot dry matter of the four plants was $33.22 \mathrm{~g} \cdot \mathrm{pot}^{-1}$, in response to the phosphate fertilization $\left(150 \mathrm{mg} \cdot \mathrm{dm}^{-3}\right.$ of 


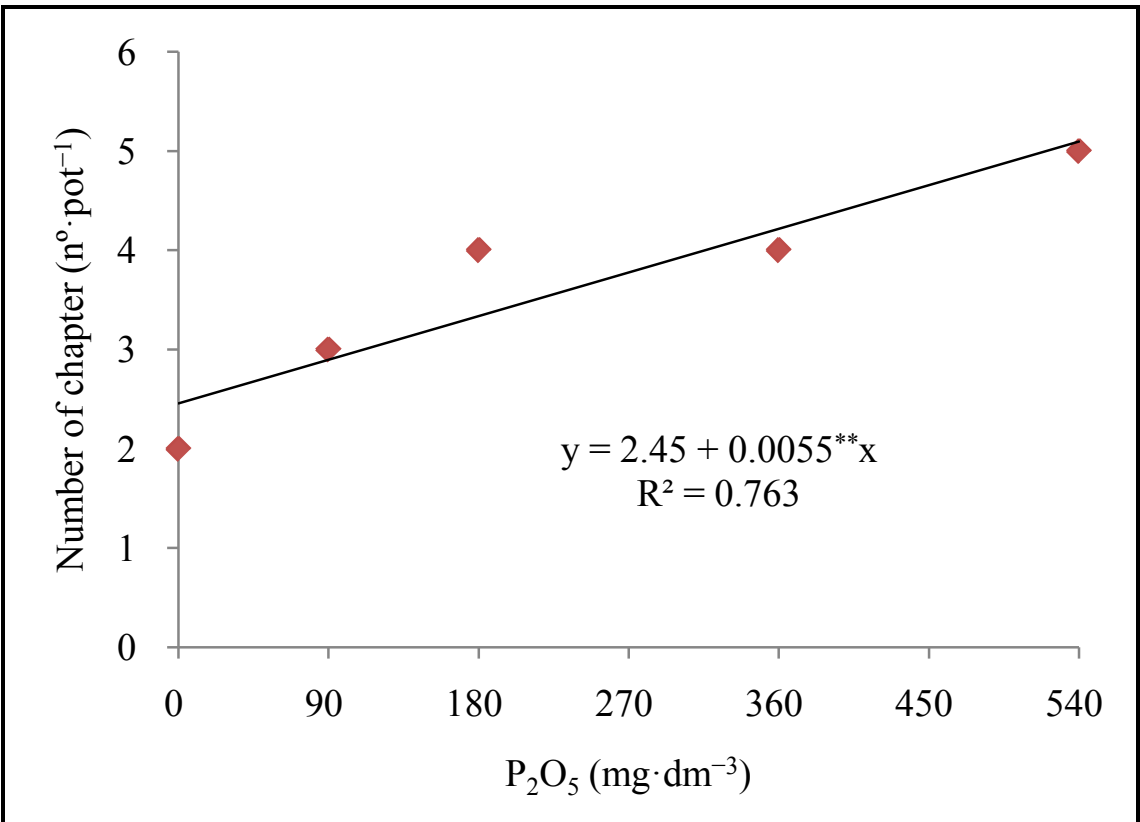

Figure 6. Number of chapter of the safflower (Carthamus tinctorius L.) on 62 days post-transplanting in response to the phosphorus doses $\left(0,90,180,360\right.$ and $540 \mathrm{mg} \cdot \mathrm{dm}^{-3}$ of $\left.\mathrm{P}_{2} \mathrm{O}_{5}\right) .{ }^{*}$ Significant at $1 \%$.

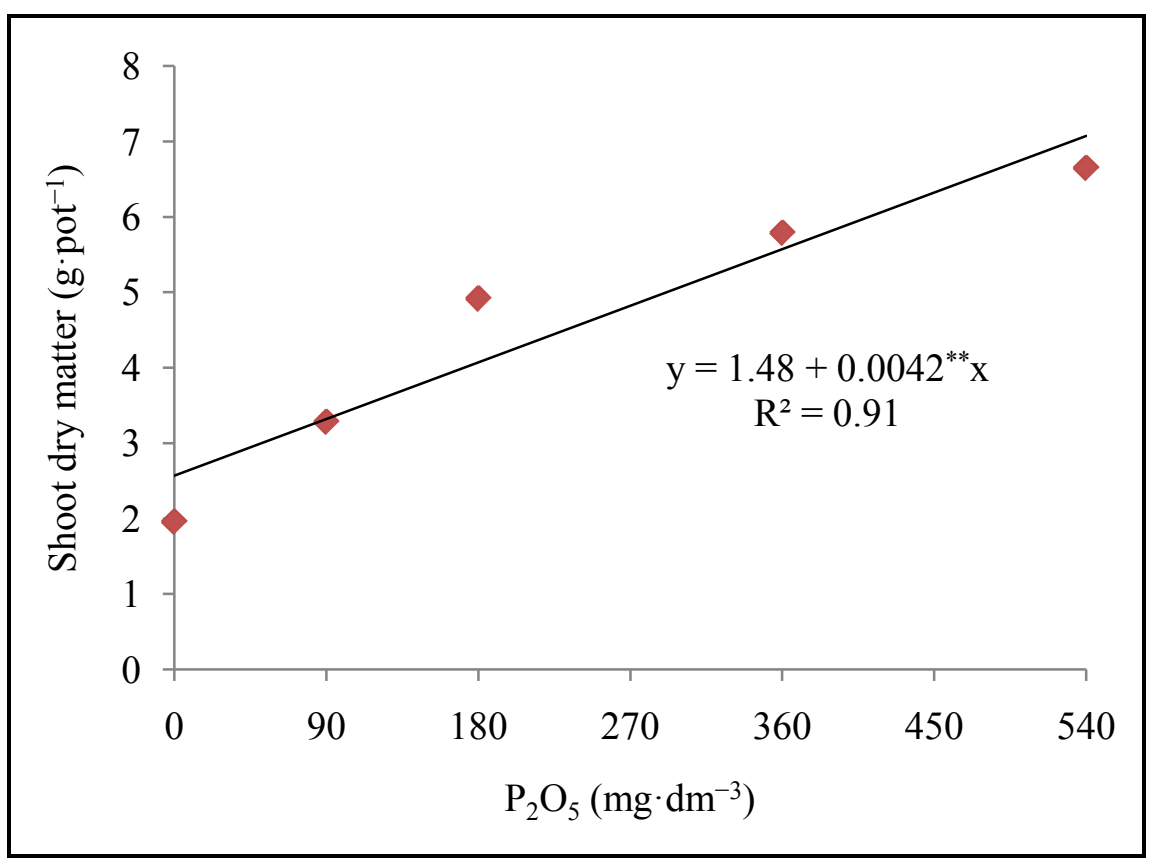

Figure 7. Shoot dry matter of the safflower (Carthamus tinctorius L.) on 62 days post-transplanting in response to the phosphorus doses $\left(0,90,180,360\right.$ and $540 \mathrm{mg} \cdot \mathrm{dm}^{-3}$ of $\left.\mathrm{P}_{2} \mathrm{O}_{5}\right)$. ${ }^{*}$ Significant at $1 \%$.

$\mathrm{P}_{2} \mathrm{O}_{5}$ ) [9]. The safflower showed a rise in production with the increased availability of the phosphorus [8]. Safflower cultivation normally responds positively to mineral fertilization, and when phosphorus and nitrogen were applied they induced a significant boost in the yield and characteristics of the components of 
production of safflower [29] [30].

Growth rate and plant productivity are contingent upon the phosphorus nutrient efficiency [30]. Phosphorus strongly influences the dry matter yield, as it directly takes part in the metabolic processes of the plants, by supplying the required energy, as well as significant constituents of several protein complexes [21] [31] [32] [33].

\section{Conclusion}

Phosphate fertilization was observed to positively affect the phytometric and productive characteristics of the safflower crop cultivated in the Oxisol of the Cerrado, demonstrating that safflower can be a viable crop that can be introduced in the Brazilian Cerrado.

\section{Acknowledgements}

Mato Grosso Cotton Institute (IMAmt) for support given in research.

\section{References}

[1] Dordas, C.A. and Sioulas, C. (2008) Safflower Yield, Chlorophyll Content, Photosynthesis, and Water Use Efficiency Response to Nitrogen Fertilization under Rainfed Conditions. Industrial Crops and Products, 27, 75-85.

https://doi.org/10.1016/j.indcrop.2007.07.020

[2] Dajue, L. and Mündel, H.H. (1996) Safflower. Carthamus tinctorius L. Promoting the Conservation and Use of Underutilized and Neglected Crops. 7th Edition, Institute of Plant Genetics and Crop Plant Research, Gatersleben/International Plant Genetic, Rome.

https://www.bioversityinternational.org/fileadmin/_migrated/uploads/tx_news/Saffl ower_Carthamus_tinctorius_L._498.pdf

[3] Sampaio, M.C., Santos, R.F., Bassegio, D., de Vasconcelos, E.S., Silva, M.A., Secco, D. and da Silva, T.R.B. (2016) Fertilizer Improves Seed and Oil Yield of Safflower under Tropical Conditions. Industrial Crops and Products, 94, 589-595.

[4] Siddiqui, M.H. and Oad, F.C. (2006) Nitrogen Requirement of Safflower (Carthamus tinctorius L.) for Growth and Yield Traits. Asian Journal of Plant Sciences, 5, 563-565. https://doi.org/10.3923/ajps.2006.563.565

[5] Velasco, L., Pérez-Vich, B. and Fernández-Martínez, J.M. (2005) Identification and Genetic Characterization of a Safflower Mutant with a Modified Tocopherol Profile. Plant Breeding, 124, 459-463. https://doi.org/10.1111/j.1439-0523.2005.01150.x

[6] Cerioni, G.A., Asnal, W.E., Fernández, E.M., Cholaki, L. and Giayetto, O. (1999) Behaviour of Safflower (Carthamus tinctorius, L.) Cultivars in Rio Cuarto Area, Córdoba (Argentina). Investigación Agraria, 14, 203-215. https://dialnet.unirioja.es/servlet/articulo?codigo $=112256$

[7] Kaffka, S.R. and Kearney, T.E. (1998) Safflower Production in California. UCANR Publications, California, 5-7.

[8] Abbadi, J. and Gerendás, J. (2011) Effects of Phosphorus Supply on Growth, Yield, and Yield Components of Safflower and Sunflower. Journal of Plant Nutrition, 34, 1769-1787. https://doi.org/10.1080/01904167.2011.600405

[9] de Anicésio, E.C.A., Bonfim-Silva, E.M., da Silva, T.J.A. and Koetz, M. (2015) Dry 
Mass, Nutrient Concentration and Accumulation in Safflower (Carthamus tinctorius $\mathrm{L}$ ) Influenced by Nitrogen and Potassium Fertilizations. Australian Journal of Crop Science, 9, 552-560.

http://www.scopus.com/inward/record.url?eid=2-s2.0-84938060220\&partnerID=40 \&md5=8d35e1b855039f4e15b81e373cb87e80

[10] Bonfim-Silva, E.M., de Anicésio, E.C.A., de Oliveira, J.R., Sousa, H.H.F. and da Silva, T.J.A. (2015) Soil Water Availabilities in the Content and Accumulation of Nitrogen and Chlorophyll Index in the Safflower. American Journal of Plant Sciences, 6, 2280-2286. https://doi.org/10.4236/ajps.2015.614231

[11] Bonfim-Silva, E.M., Pacheco, A.B., Silva, T.J.A., do Espirito Santo, E.S., Bär, C.S.L. e Lima and Sousa, H.H. de F. (2016) Biometric Characteristics and Visual Diagnosis of Safflower Plants under Macro and Micronutrient Omission. International Journal of Current Research, 8, 31071-31076.

[12] IBGE (2017) Agricultural Production Statistics. 74.

[13] Furtini Neto, A.E., Vale, F.R., Resende, A.V., Guilherme, L.R.G. and Guedes, G.A.A. (2001) Soil Fertility. UFLA/FAEPE, Lavras.

[14] Centre, P.C. and Wetterdienst, D. (2006) World Map of the Köppen-Geiger Climate Classification Updated. Meteorologische Zeitschrift, 15, 259-263. https://doi.org/10.1127/0941-2948/2006/0130

[15] Embrapa (1997) Manual of Soil Analysis Methods. 2nd Edition, National Soil Research Center, Rio de Janeiro.

[16] Raij, B.V. (2011) Soil Fertility and Nutrient Management. UFV, Viçosa.

[17] Paludo, J.T.S. (2015) Safflower Genotypes of Agriculture Performance Subject to Compaction in Oxisol. Ms.c Pós-graduação em Engeharia Agrícola, Universidade Federal de Mato Grosso.

http://www.ufmt.br/pgeagri/arquivos/dbfd516c263ff630e96ee6097646a799.pdf

[18] Bonfim-Silva, E.M., Silva, T.J.A. da, Cabral, C.E.A., Gonçalves, J.M. and Pereira, M.T.J. (2011) Production and Morphology of Java Legumes Submitted to Phosphorus. Enciclopédia Biosfera, Centro Científico Conhecer, 7, 1-10. http://www.conhecer.org.br/enciclop/2011a/agrarias/producao e morfologia.pdf

[19] Ferreira, D.F. (2011) Sisvar: A Computer Statistical Analysis System. Ciencia e Agrotecnologia, 35, 1039-1042. https://doi.org/10.1590/S1413-70542011000600001

[20] Silva, P.C.C., Alves, A.C., Jesus, F.N. de, Lobo, D.M. and Santos, A.R. dos. (2012) Growth and Yield of Dry Matter in Sunflower Subjected to Phosphate Fertilization in a Yellow Latosol. Enciclopédia Biosfera, Centro Científico Conhecer, 8, 283-293. http://www.conhecer.org.br/enciclop/2012a/agrarias/crescimento e rendimento.pdf

[21] Malavolta, E., Vitti, G.C. and Oliveira, S.A. (1997) Plant Nutrition Status Assessment: Principles and Applications. 2nd Edition, Potafós, Piracicaba.

[22] Bonfim-Silva, E.M., da Silva, T.J.A., Cabral, C.E.A., Kroth, B.E. and Rezende, D. (2011) Initial Development of Grasses Under Water Stress. Revista Caatinga, 24, 180-186.

[23] Fernades, A.R. and Leite, A.R.P. (2004) Soil Management and Fertilizer Use for Sorghum Silage Production. $1^{\mathrm{o}}$ Workshop Sobre Produção de Silagem Na Amazônia, Universidade Federal Rural da Amazônia, Belém, 53-64.

[24] Santos, L.G. dos, Souza, U.O., Primo, D.C., Silva, P.C.C. and Santos, A.R. dos. (2010) Nutritional Condition of Sunflower Cultivation Submitted to Phosphorus and Boron Tillering. Enciclopédia Biosfera, Centro Científico Conhecer, 6, 1-14. http://www.conhecer.org.br/enciclop/2010c/estado nutricional.pdf 
[25] Machado, C.T. de T., Furlani, A.M.C. and Machado, A.T. (2001) Phosphorus Efficiency Index of Local and Improved Corn Varieties. Bragantia, 60, 225-238. https://doi.org/10.1590/S0006-87052001000300010

[26] Moreira, F.M. and Siqueira, J.O. (2006) Microbiology and Soil Biochemistry. 2nd Edition, Editora Lavras, Lavras.

[27] Andriolo, J.L. (1999) Physiology of Protected Plants. Editora UFSM, Santa Maria.

[28] Silva, E.F.L., de Araújo, A.S.F., dos Santos, V.B., Nunes, L.A.P.L. and Carneiro, R.F.V. (2010) Biological $\mathrm{N}_{2}$ Fixation in Cowpea Under Different Rates and Sources of Soluble Phosphorus. Bioscience Journal, 26, 394-402.

[29] Gerhardt, I.F.S. (2014) Genetic Divergence between Safflower Accesses (Carthamus Tinctorius L.). UNESP.

[30] Golzarfar, M., Rad, A., Delkhosh, B. and Bitarafan, Z. (2012) Safflower (Carthamus tinctorius L.) Response to Different Nitrogen and Phosphorus Fertilizer Rates in Two Planting Seasons. Zemdirbyste, 99, 159-166. http://www.lzi.lt/tomai/99(2)tomas/99_2_tomas_str6.pdf

[31] Sary, G.A., El-Deepah, H.R.A. and Khaled, M.A.I. (1998) Effect of Plant Density and Fertilization on Yield of Safflower. Annals of Agriculture Science, 26, 1381-1398.

[32] Zobiole, L.H.S., Castro, C. de, Oliveira, F.A. de and Oliveira Junior, A. de. (2010) Macronutrient Uptake of Sunflower (Helianthus annuus L.). Revista Brasileira de Ciencia do Solo, 34, 425-433. https://doi.org/10.1590/S0100-06832010000200016

[33] Tomich, T.R., Rodrigues, J.A.S., Gonçalves, L.C., Tomich, R.G.P. and Carvalho, A.U. (2003) Forage Potential of Sunflower Cultivars Produced in Double-Cropping System for Silage. Arquivo Brasileiro de Medicina Veterinaria e Zootecnia, 55, 756-762. https://doi.org/10.1590/S0102-09352003000600013 